[Article]

\title{
铁铜双金属催化剂选择性催化氧化氨为氮气
}

\author{
孙萌萌 曹 毅 兰 丽 邹 莎 房志涛陈耀强 \\ (四川大学化学学院, 教育部绿色化学重点实验室, 成都 610064)
}

\begin{abstract}
摘要: 固定铜铁的总质量不变, 采用共浸渍法制备铜铁双金属催化剂. 为了更好地了解催化剂的性质, 分别用 $\mathrm{N}_{2}$ 吸附-脱附、 $\mathrm{H}_{2}$-程序升温还原 $\left(\mathrm{H}_{2}-\mathrm{TPR}\right) 、 \mathrm{NH}_{3}$-程序升温脱附 $\left(\mathrm{NH}_{3}-\mathrm{TPD}\right) 、 \mathrm{X}$ 射线衍射 $(X R D)$ 和 $X$ 射线光电子能 谱(XPS)方法对制备的催化剂进行表征. 研究发现在 $100000 \mathrm{~h}^{-1}$ 空速下, 铜铁双金属催化剂呈现出好的活性和 氮气选择性. 在低温区, 随着铜含量的增加, 活性和氮气的选择性增加, 然而在高温区氮气的选择性直接和铁的 含量相关. 其中催化剂 $\mathrm{Fe}_{0.25} \mathrm{Cu}_{0.75} / \mathrm{ZSM}-5$, 在 $350{ }^{\circ} \mathrm{C}$ 氨的转化率达到最高, 在 $300{ }^{\circ} \mathrm{C}$ 氮气的选择性上升到 $97 \%$. $\mathrm{Fe}_{0.75} \mathrm{Cu}_{0.25} / \mathrm{ZSM}-5$ 在 $500{ }^{\circ} \mathrm{C}$ 有很高的氮气选择性甚至可以达到 $98 \%$. 并且所有的催化剂均产生很少的 $\mathrm{N}_{2} \mathrm{O}$ 副产物. 表征结果显示催化剂的酸量和铜物种的含量可以影响催化剂的活性, 并且高的还原能力和铁含量 有助于高温氮气选择性的提高.
\end{abstract}

关键词：铁； 铜；分子篮；氨氧化反应； $\mathrm{N}_{2}$ 选择性；催化剂

中图分类号: 0643

\section{Selective Catalytic Oxidation of Ammonia to Nitrogen over Iron and Copper Bimetallic Catalysts}

\author{
SUN Meng-Meng CAO Yi LAN Li ZOU Sha FANG Zhi-Tao CHEN Yao-Qiang* \\ (Key Laboratory of Green Chemistry \& Technology of the Ministry of Education, College of Chemistry, \\ Sichuan University, Chengdu 610064, P. R. China)
}

\begin{abstract}
Iron and copper bimetallic catalysts with fixed total contents of copper and iron were prepared by a co-impregnation method, and then used for selective catalytic oxidation of ammonia to nitrogen. The properties of the catalysts were characterized by $\mathrm{N}_{2}$ adsorption-desorption, $\mathrm{H}_{2}$ temperature-programmed reduction $\left(\mathrm{H}_{2}\right.$ TPR), $\mathrm{NH}_{3}$ temperature-programmed desorption $\left(\mathrm{NH}_{3}-\mathrm{TPD}\right)$, $\mathrm{X}$-ray diffraction (XRD), and $\mathrm{X}$-ray photoelectron spectroscopy (XPS). The iron and copper bimetallic catalysts exhibited good activity and high selectivity of $\mathrm{N}_{2}$ at the gas hourly space velocity (GHSV) of $100000 \mathrm{~h}^{-1}$. The activity and $\mathrm{N}_{2}$ selectivity in the low temperature range increased with increasing $\mathrm{Cu}$ loading, whereas in the high temperature range (above $400{ }^{\circ} \mathrm{C}$ ) the selectivity of $\mathrm{N}_{2}$ was directly related to the content of iron. The highest $\mathrm{NH}_{3}$ conversion was achieved at about $350{ }^{\circ} \mathrm{C}$ for $\mathrm{Fe}_{0.25} \mathrm{Cu}_{0.75} / \mathrm{ZSM}-5$, and the $\mathrm{N}_{2}$ selectivity was up to $97 \%$ at $300{ }^{\circ} \mathrm{C}$. On the other hand, the extremely high $\mathrm{N}_{2}$ selectivity about $98 \%$ was obtained over $\mathrm{Fe}_{0.75} \mathrm{Cu}_{0.25} / \mathrm{ZSM}-5$ at $500{ }^{\circ} \mathrm{C}$. In addition, $\mathrm{N}_{2} \mathrm{O}$ as the by-product and greenhouse gas was obtained in very low amounts for all the catalysts. The characterization results showed that the activity was influenced by the acid content and the amounts of copper species. Moreover, the highly reducing capacity could improve the $\mathrm{N}_{2}$ selectivity.
\end{abstract}

Key Words: Iron; Copper; Molecular sieve; Ammonia oxidation reaction; $\mathrm{N}_{2}$ selectivity; Catalyst

Received: June 16, 2014; Revised: September 29, 2014; Published on Web: September 29, 2014.

"Corresponding author. Email: nic7501@scu.edu.cn; Tel: +86-28-85418451; Fax: +86-28-85418451.

The project was supported by the National Natural Science Foundation of China (21173153), National High-Tech Research and Development Program of China (863) (2013AA065304), and Major Research Program of Sichuan Province Science and Technology Department, China (2011GZ0035, 2012FZ0008).

国家自然科学基金(21173153), 国家高技术研究发展计划项目(863) (2013AA065304)及四川省科技厅科技支撑项目(2011GZ0035, 2012FZ0008)资助

(c) Editorial office of Acta Physico-Chimica Sinica 


\section{Introduction}

$\mathrm{NH}_{3}$ is seen as a toxic gas with a pungent odor, and shows potential damage to public safety, ${ }^{1}$ which is used as reactants in a lot of chemical processes such as nitric acid production and urea manufacturing. As a byproduct, it is produced in many reactions such as de-nitration process. Thus environmental problems induced by ammonia emission become more severe. Selective catalytic oxidation (SCO) of ammonia to molecular nitrogen and water is proposed as an efficient and promising method to solve problems of ammonia pollution, and it has become increasingly important in recent years.

The catalytic oxidation of ammonia can proceed three reactions: ${ }^{2,3}$

$4 \mathrm{NH}_{3}+3 \mathrm{O}_{2} \rightarrow 2 \mathrm{~N}_{2}+6 \mathrm{H}_{2} \mathrm{O}$

$4 \mathrm{NH}_{3}+5 \mathrm{O}_{2} \rightarrow 4 \mathrm{NO}+6 \mathrm{H}_{2} \mathrm{O}$

$2 \mathrm{NH}_{3}+2 \mathrm{O}_{2} \rightarrow \mathrm{N}_{2} \mathrm{O}+3 \mathrm{H}_{2} \mathrm{O}$

Except that the reaction (1) mentioned above is promoted, reactions (2) and (3) should be prevented due to the production of toxic nitrogen oxide.

To achieve such goal, various catalysts (e.g., noble metal catalysts, transition metal catalysts) for oxidizing $\mathrm{NH}_{3}$ have been developed. The noble metals (e.g., Pt, Pd, Rh, Ag) are active for ammonia oxidation reaction, ${ }^{4-9}$ but the selectivity of $\mathrm{N}_{2}$ is low. The transition metal catalysts such as $\mathrm{V}_{2} \mathrm{O}_{5}, \mathrm{Fe}_{2} \mathrm{O}_{3}, \mathrm{CuO}, \mathrm{MnO}_{2}, \mathrm{TiO}_{2}$ are also employed for the ammonia oxidation reaction. Among them $\mathrm{Fe}_{2} \mathrm{O}_{3}$ and $\mathrm{CuO}$ have attracted much attention. ${ }^{10,11}$ Such as high activity of ammonia oxidation at high temperatures via Febased catalysts is well studied by Yang et al. ${ }^{12-14}$ However, the activity over Fe-based catalysts is very low at low temperatures. For copper-based catalysts, they behave quite opposite to Febased catalysts, i.e., better activity is observed at low temperatures for copper-based catalysts. ${ }^{15-19}$ Thus it is necessary to prepare the catalysts with both $\mathrm{Cu}$ and $\mathrm{Fe}$, which can improve the activity at low temperatures as well as the $\mathrm{N}_{2}$ selectivity. In this study, copper and iron catalysts were loaded into the routine support materials (ZSM-5) with different $\mathrm{Cu} / \mathrm{Fe}$ mass ratios, in order for developing a better catalyst to improve the activity and $\mathrm{N}_{2}$ selectivity for the ammonia oxidation reaction.

\section{Experimental}

\subsection{Preparation of catalysts}

The samples were synthesized by an impregnation method using $\mathrm{FeCl}_{2} \cdot 4 \mathrm{H}_{2} \mathrm{O}$ (A.R.) and $\mathrm{Cu}\left(\mathrm{NO}_{3}\right)_{2} \cdot 3 \mathrm{H}_{2} \mathrm{O}$ (A.R.) as the metal precursors. ZSM-5 $\left(\mathrm{SiO}_{2} / \mathrm{Al}_{2} \mathrm{O}_{3}\right.$ molar ratio=25) was purchased in Nankai University Catalyst Factory as the support. The total content of copper and iron was maintained at $4 \%$ (mass fraction, without cordierite). Three different catalysts with different $\mathrm{Cu} / \mathrm{Fe}$ mass ratios were prepared, namely $\mathrm{Fe}_{0.25} \mathrm{Cu}_{0.75} / \mathrm{ZSM}-5, \mathrm{Fe}_{0.50} \mathrm{Cu}_{0.50} /$ ZSM-5, and $\mathrm{Fe}_{0.75} \mathrm{Cu}_{0.25} / \mathrm{ZSM}-5$. After impregnation, the samples were dried in the oven. And then the sample was calcined at $300{ }^{\circ} \mathrm{C}$ for $2 \mathrm{~h}$ and $550{ }^{\circ} \mathrm{C}$ for $3 \mathrm{~h}$. After that, the catalyst powders with certain distilled water were ball-milled to form homogeneous slurry. The slurry was coated on a honeycomb cordierite (5.2 $\mathrm{cm}^{3}$, Corning, America) with the coating amount of $160 \mathrm{~g} \cdot \mathrm{L}^{-1}$.
$\mathrm{Fe}_{1-x} \mathrm{Cu}_{x} / \mathrm{ZSM}-5(x=0.75,0.50,0.25)$ with cordierites was used to evaluate the performance of catalysts.

\subsection{Characterization of catalysts}

$\mathrm{N}_{2}$ adsorption-desorption isotherms were measured at $-196{ }^{\circ} \mathrm{C}$ on a QUANTACHROME SI automated surface area \& pore size Analyzer. Before each measurement, the catalyst powders (without cordierite) were degassed at $300{ }^{\circ} \mathrm{C}$ for $3 \mathrm{~h}$ under vacuum. The specific surface area and the pore size distribution of the catalyst powders were calculated using the Brunauer-EmmettTeller (BET) and Barrett-Joyner-Halenda (BJH) methods, respectively.

$\mathrm{H}_{2}$ temperature-programmed reduction $\left(\mathrm{H}_{2}-\mathrm{TPR}\right)$ was carried out in a quartz tubular micro-reactor equipped with a thermal conductivity detector (TCD). Prior to the analysis, $0.10 \mathrm{~g}$ of sample (without cordierite) was loaded into the quartz tubular micro-reactor and then pretreated with a flow of $\mathrm{N}_{2}$ for $1 \mathrm{~h}$ at $450{ }^{\circ} \mathrm{C}$. Afterwards, the sample was cooled to room temperature in $\mathrm{N}_{2}$. The measurement was performed from room temperature to $750{ }^{\circ} \mathrm{C}$ in a flow of $5 \% \mathrm{H}_{2} / \mathrm{N}_{2}$ at a heating rate of $8{ }^{\circ} \mathrm{C} \cdot \mathrm{min}^{-1}$.

$\mathrm{NH}_{3}$ temperature-programmed desorption $\left(\mathrm{NH}_{3}-\mathrm{TPD}\right)$ was detected by a TCD. $0.10 \mathrm{~g}$ of the catalyst powders (without cordierite) was first pretreated at $450{ }^{\circ} \mathrm{C}$ for $1 \mathrm{~h}$. Subsequently, the sample was cooled to $60^{\circ} \mathrm{C}$. After that, ammonia was adsorbed at $60{ }^{\circ} \mathrm{C}$ for $1 \mathrm{~h}$, and the excess $\mathrm{NH}_{3}$ was purged using $\mathrm{He}$, then the temperature was increased linearly to $600{ }^{\circ} \mathrm{C}$ with flowing $\mathrm{He}$ at a heating rate of $10^{\circ} \mathrm{C} \cdot \mathrm{min}^{-1}$.

The powder X-ray diffraction (XRD) patterns were recorded on a D/max-rA diffractometer (RIGAKU Corp.) with $\mathrm{Cu} K_{\alpha}$ radiation (40 kV, $25 \mathrm{~mA}, \lambda=0.15406 \mathrm{~nm}$ ). During analysis, the sample (without cordierite) was scanned from $5^{\circ}$ to $60^{\circ}$. The compound was identified by comparison with reference data from the International Centre for Diffraction Data (ICDD).

$\mathrm{X}$-ray photoelectron spectra of samples were performed using an AXIS Ultra DLD (KRATOS) spectrometer with $\mathrm{Al} K_{\alpha}$ radiation $(1486.6 \mathrm{eV})$. X-ray radiation was operated at $300 \mathrm{~W}$ by setting the electron energy analyzer.

\subsection{Performance evaluation of catalysts}

The catalytic reaction for ammonia selective catalytic oxidation was carried out under atmospheric pressure in a temperatureprogrammed reaction fixed-bed quartz-glass reactor. The inlet and outlet gas compositions were analyzed by an on-line ANTARIS IGS Analyzer. The reactant gas composition was as follows: $2 \times 10^{-8}$ (volume fraction) $\mathrm{NH}_{3}, 10 \% \mathrm{O}_{2}, 8 \% \mathrm{CO}_{2}$, and balance $\mathrm{N}_{2}$. The gas hourly space velocity (GHSV) was $100000 \mathrm{~h}^{-1}$. Before running an experiment, the catalyst (with cordierite) was pretreated under the reaction atmosphere at $500{ }^{\circ} \mathrm{C}$ for $1 \mathrm{~h}$ to make the property of catalyst stable. Then the temperature was decreased to the reaction temperature. Data were collected in a steady state. The $\mathrm{NH}_{3}$ conversion and $\mathrm{N}_{2} \mathrm{O}$ selectivity were defined as:

$\mathrm{NH}_{3}$ conversion $=\left(\left[\mathrm{NH}_{3}\right]_{\text {in }}-\left[\mathrm{NH}_{3}\right]_{\text {out }}\right) /\left[\mathrm{NH}_{3}\right]_{\text {in }} \times 100 \%$

$\mathrm{N}_{2} \mathrm{O}$ selectivity $=2\left[\mathrm{~N}_{2} \mathrm{O}\right]_{\text {out }} /\left(\left[\mathrm{NH}_{3}\right]_{\text {in }}-\left[\mathrm{NH}_{3}\right]_{\text {out }}\right) \times 100 \%$

It was impossible to directly measure $\mathrm{N}_{2}$ by Fourier transform infrared (FTIR) spectrometry. $\mathrm{N}_{2}$ selectivity was calculated based 
on the following formula:

$\mathrm{N}_{2}$ selectivity $=\left(\left[\mathrm{NH}_{3}\right]_{\text {in }}-\left[\mathrm{NH}_{3}\right]_{\text {out }}-[\mathrm{NO}]_{\text {out }}-\left[\mathrm{NO}_{2}\right]_{\text {out }}-2\left[\mathrm{~N}_{2} \mathrm{O}\right]_{\text {out }}\right) /$ $\left(\left[\mathrm{NH}_{3}\right]_{\text {in }}-\left[\mathrm{NH}_{3}\right]_{\text {out }}\right) \times 100 \%$

\section{Results and discussion}

\subsection{Property of catalysts}

The ammonia oxidation reaction was studied on the $\mathrm{Fe}_{1-x} \mathrm{Cu}_{x} /$ ZSM-5 $(x=0.25,0.50,0.75)$ catalysts (with cordierite). Fig. 1 showed the results of $\mathrm{NH}_{3}$ conversion in ammonia oxidation reaction. We could clearly see that the activity increased by increasing temperature for all the catalysts. When the appropriate amount of copper and iron was mixed, a significant influence on catalytic activity in low temperature range was observed. We found that the activity increased by increasing the mass ratio of $\mathrm{Cu} / \mathrm{Fe}$ at $225-400{ }^{\circ} \mathrm{C}$. For $\mathrm{Fe}_{0.75} \mathrm{Cu}_{0.25} / \mathrm{ZSM}-5$ catalyst, the $\mathrm{NH}_{3}$ conversion was only $84 \%$ at $500{ }^{\circ} \mathrm{C}$. However, $90 \% \mathrm{NH}_{3}$ conversion was achieved for $\mathrm{Fe}_{0.50} \mathrm{Cu}_{0.50} / \mathrm{ZSM}-5$ and $\mathrm{Fe}_{0.25} \mathrm{Cu}_{0.75} / \mathrm{ZSM}-$ 5 catalysts at about 390 and $327^{\circ} \mathrm{C}$, respectively. The results of activity suggested that copper was more active than the same amount of iron at low temperatures.

Fig.2a displayed the $\mathrm{N}_{2}$ selectivity on $\mathrm{Fe}_{1-x} \mathrm{Cu}_{x} / \mathrm{ZSM}-5$ catalysts. All the catalysts exhibited high selectivity to $\mathrm{N}_{2}$, in which the $\mathrm{N}_{2}$ selectivity increased by increasing the mass ratio of $\mathrm{Cu} / \mathrm{Fe}$ at lower temperatures $\left(<400{ }^{\circ} \mathrm{C}\right)$, while the selectivity of $\mathrm{N}_{2}$ increased by decreasing the mass ratio of $\mathrm{Cu} / \mathrm{Fe}$ at higher temperatures $\left(>400{ }^{\circ} \mathrm{C}\right)$. For example, the $\mathrm{N}_{2}$ selectivity approached $97 \%$ for $\mathrm{Fe}_{0.25} \mathrm{Cu}_{0.75} / \mathrm{ZSM}-5$ catalyst at $300{ }^{\circ} \mathrm{C}$ and decreased by increasing the temperature, even the $\mathrm{N}_{2}$ selectivity was still $88 \%$ at $500{ }^{\circ} \mathrm{C}$. The $\mathrm{N}_{2}$ selectivity of $\mathrm{Fe}_{0.50} \mathrm{Cu}_{0.50} / \mathrm{ZSM}-5$ behaved much better than $\mathrm{Fe}_{0.75} \mathrm{Cu}_{0.25} / \mathrm{ZSM}-5$ due to the increasing mass ratio of $\mathrm{Cu} / \mathrm{Fe}$ below $400{ }^{\circ} \mathrm{C}$. However, the $\mathrm{N}_{2}$ selectivity was close, regardless of the $\mathrm{Cu} / \mathrm{Fe}$ mass ratio in the temperature range from 400 to $500{ }^{\circ} \mathrm{C}$. In details, the $\mathrm{Fe}_{0.75} \mathrm{Cu}_{0.25} / \mathrm{ZSM}-5$ catalyst with the highest iron loading exhibited the best selectivity of $\mathrm{N}_{2}(98 \%)$ at $500{ }^{\circ} \mathrm{C}$.

From Fig.2b, we could clearly see that the selectivity of $\mathrm{N}_{2} \mathrm{O}$ was relatively low $(<5 \%)$ for all catalysts. Moreover, $\mathrm{Cu}$ con-

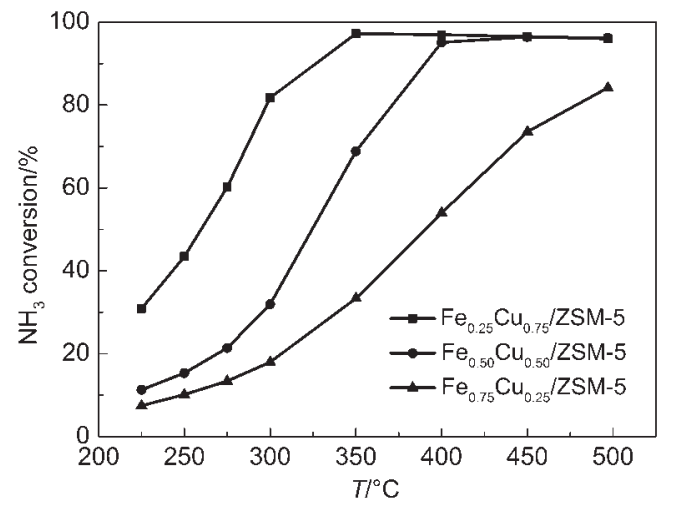

Fig.1 $\mathrm{NH}_{3}$ conversion over $\mathrm{Fe}_{0.25} \mathrm{Cu}_{0.75} / \mathrm{ZSM}-5, \mathrm{Fe}_{0.5} \mathrm{Cu}_{0.5} / \mathrm{ZSM}-5$, and $\mathrm{Fe}_{0.75} \mathrm{Cu}_{0.25} / \mathrm{ZSM}-5$ catalysts

experimental condition: $2 \times 10^{-8}$ (volume fraction) $\mathrm{NH}_{3}, 10 \% \mathrm{O}_{2}, 8 \% \mathrm{CO}_{2}$, and balanced with $\mathrm{N}_{2}$. The gas hourly space velocity (GHSV) was $100000 \mathrm{~h}^{-1}$.
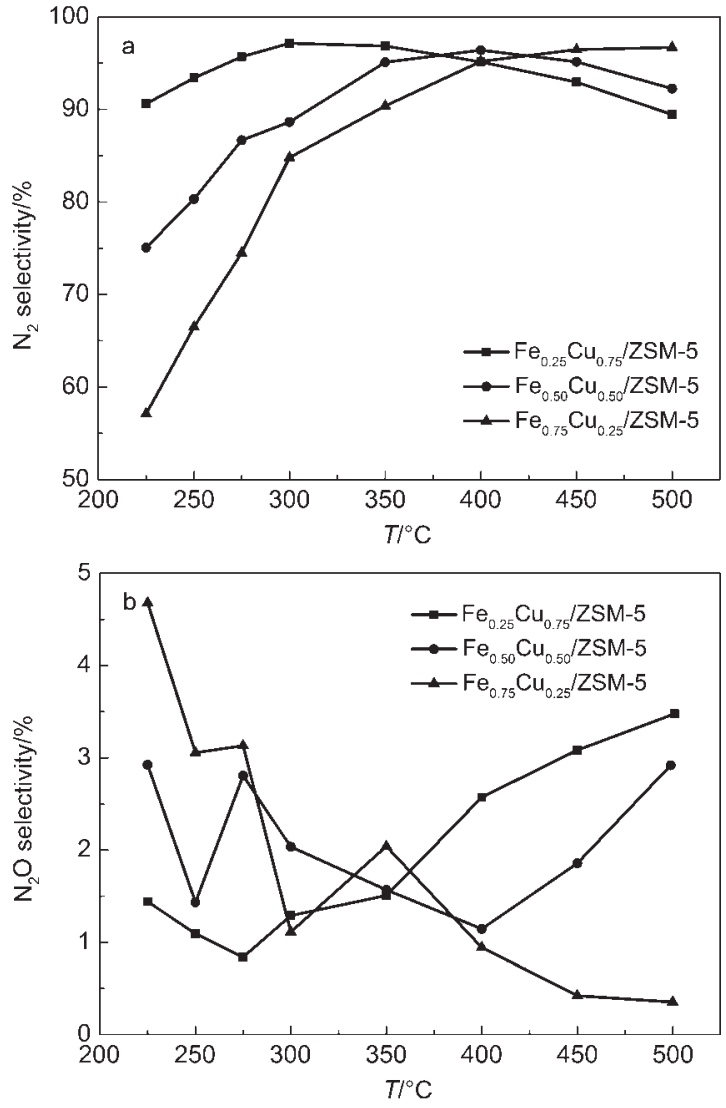

Fig.2 $\mathrm{N}_{2}$ selectivity (a) and $\mathrm{N}_{2} \mathrm{O}$ selectivity (b) over $\mathrm{Fe}_{1-x} \mathrm{Cu}_{x} / \mathrm{ZSM}-5$ catalysts

experimental condition: $2 \times 10^{-8} \mathrm{NH}_{3}, 10 \% \mathrm{O}_{2}, 8 \% \mathrm{CO}_{2}$, and balanced with $\mathrm{N}_{2}$; $\mathrm{GHSV}=100000 \mathrm{~h}^{-1}$

tributed to the low $\mathrm{N}_{2} \mathrm{O}$ selectivity at relative low temperatures while $\mathrm{Fe}$ replaced the role of $\mathrm{Cu}$ at high temperatures.

Fig. 3 showed the $\mathrm{NH}_{3}$ conversion over $\mathrm{Fe}_{0.25} \mathrm{Cu}_{0.75} / \mathrm{ZSM}-5$ sample at $350{ }^{\circ} \mathrm{C} .97 \% \mathrm{NH}_{3}$ conversion was observed under the condition of $2 \times 10^{-8}$ (volume fraction) $\mathrm{NH}_{3}, 10 \% \mathrm{O}_{2}, 8 \% \mathrm{CO}_{2}$, balanced with $\mathrm{N}_{2}$ and GHSV $=100000 \mathrm{~h}^{-1}$. When $5 \times 10^{-7}$ (volume fraction) $\mathrm{SO}_{2}$ was added into the reaction, $\mathrm{NH}_{3}$ conversion sharply decreased to $38 \%$ in $0.5 \mathrm{~h}$, then slightly went down to $23 \%$ in $2 \mathrm{~h}$. However, $\mathrm{NH}_{3}$ conversion increased to $65 \%$ after turning off the

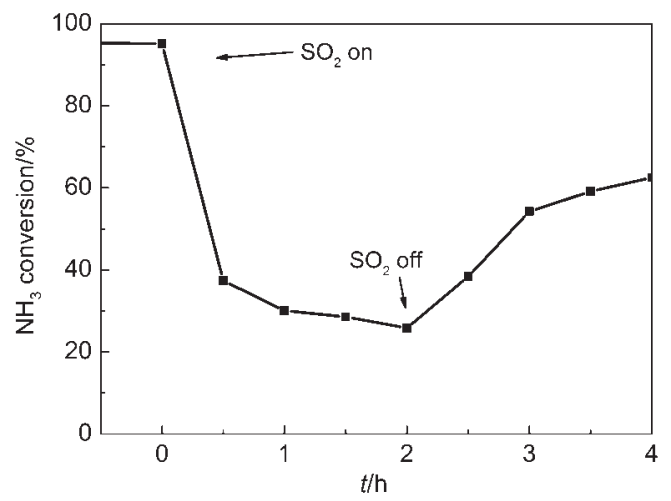

Fig.3 $\mathrm{NH}_{3}$ conversion over $\mathrm{Fe}_{0.25} \mathrm{Cu}_{0.75} / \mathrm{ZSM}-5$ catalyst at $350{ }^{\circ} \mathrm{C}$ experimental condition: $2 \times 10^{-8} \mathrm{NH}_{3}, 5 \times 10^{-7}$ (volume fraction) $\mathrm{SO}_{2}$ (when used), $10 \% \mathrm{O}_{2}, 8 \% \mathrm{CO}_{2}$, and balanced with $\mathrm{N}_{2}$; GHSV $=100000 \mathrm{~h}^{-1}$ 
$\mathrm{SO}_{2}$. Fig.4 showed the $\mathrm{NH}_{3}$ conversion over $\mathrm{Fe}_{0.25} \mathrm{Cu}_{0.75} / \mathrm{ZSM}-5$ sample after regeneration at $550{ }^{\circ} \mathrm{C}$ for $1 \mathrm{~h}$. The $\mathrm{NH}_{3}$ conversion was increased by increasing the temperature. $\mathrm{The}_{3} \mathrm{NH}_{3}$ conversion exhibited some decrease compared with the fresh catalyst below $350{ }^{\circ} \mathrm{C}$, but the high $\mathrm{NH}_{3}$ conversion $(>93 \%$ ) was still obtained from 350 to $500{ }^{\circ} \mathrm{C}$. The results indicated that $\mathrm{SO}_{2}$ tolerance of the catalyst was not very good, but the activity was mostly recovered after regeneration.

Fig.5 exhibited the $\mathrm{NH}_{3}$ conversion and $\mathrm{N}_{2}$ selectivity of $\mathrm{Fe}_{0.25} \mathrm{Cu}_{0.75} / \mathrm{ZSM}-5$ catalyst after severely aging at $800{ }^{\circ} \mathrm{C}$ for $10 \mathrm{~h}$ in air with $5 \% \mathrm{H}_{2} \mathrm{O} . \mathrm{NH}_{3}$ conversion increased with increasing the temperature. In addition, $90 \% \mathrm{NH}_{3}$ conversion was observed at $390{ }^{\circ} \mathrm{C}$ and the highest $\mathrm{NH}_{3}$ conversion (about 95\%) was obtained at $450{ }^{\circ} \mathrm{C}$. We also found that $\mathrm{Fe}_{0.25} \mathrm{Cu}_{0.75} / \mathrm{ZSM}-5$ catalyst had $76 \%$ $\mathrm{N}_{2}$ selectivity at $300{ }^{\circ} \mathrm{C}$. Furthermore, the selectivity of $\mathrm{N}_{2}$ went up to $82 \%$ at $400{ }^{\circ} \mathrm{C}$. The lowest $\mathrm{N}_{2}$ selectivity was still $58 \%$ at $500{ }^{\circ} \mathrm{C}$.

\subsection{Textural properties of catalysts}

Table 1 listed the textural parameters of $\mathrm{Fe}_{1_{-x}} \mathrm{Cu}_{x} / \mathrm{ZSM}-5$ catalysts. The adsorption-desorption isotherm shape of $\mathrm{Fe}_{1-x} \mathrm{Cu}_{x} / \mathrm{ZSM}-$ 5 catalysts remained unchanged compared with ZSM-5 zeolite.

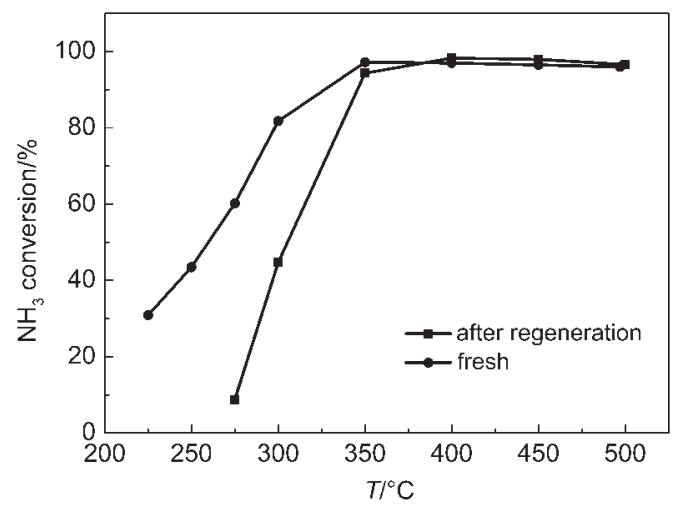

Fig.4 $\mathrm{NH}_{3}$ conversion over $\mathrm{Fe}_{0.25} \mathrm{Cu}_{0.75} / \mathrm{ZSM}-5$ catalyst after regeneration at $550{ }^{\circ} \mathrm{C}$ for $1 \mathrm{~h}$

experimental condition: $2 \times 10^{-8} \mathrm{NH}_{3}, 10 \% \mathrm{O}_{2}, 8 \% \mathrm{CO}_{2}$, and balanced with $\mathrm{N}_{2}$; GHSV $=100000 \mathrm{~h}^{-1}$

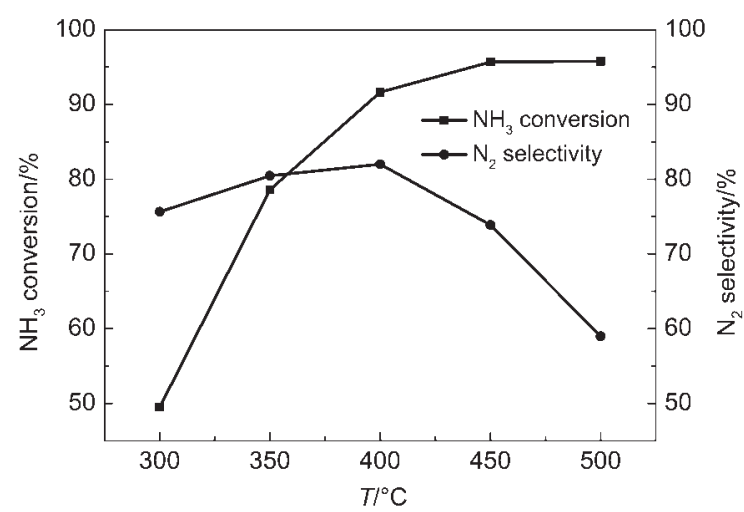

Fig.5 $\mathrm{NH}_{3}$ conversion and $\mathrm{N}_{2}$ selectivity of the $\mathrm{Fe}_{0.25} \mathrm{Cu}_{0.75} / \mathrm{ZSM}-5$ catalyst after aging at $800{ }^{\circ} \mathrm{C}$ for $10 \mathrm{~h}$ in air with $5 \% \mathrm{H}_{2} \mathrm{O}$ experimental condition: $2 \times 10^{-8} \mathrm{NH}_{3}, 10 \% \mathrm{O}_{2}, 8 \% \mathrm{CO}_{2}$, and balanced with $\mathrm{N}_{2}$; GHSV $=100000 \mathrm{~h}^{-1}$
Table 1 Textural parameters of $\mathrm{Fe}_{1-x} \mathrm{Cu}_{x} / \mathrm{ZSM}-5$ catalysts

\begin{tabular}{ccccc}
\hline Sample & Surface area & & Pore volume & $\begin{array}{c}\text { Average pore } \\
\text { diameter/nm }\end{array}$ \\
\cline { 2 - 3 } & $\left(\mathrm{m}^{2} \cdot \mathrm{g}^{-1}\right)$ & & $\left(\mathrm{cm}^{3} \cdot \mathrm{g}^{-1}\right)$ & \\
\hline ZSM-5 & 335.1 & 0.19 & 2.30 \\
$\mathrm{Fe}_{0.25} \mathrm{Cu}_{0.75} / \mathrm{ZSM}-5$ & 298.0 & & 0.18 & 2.47 \\
$\mathrm{Fe}_{0.50} \mathrm{Cu}_{0.50} / \mathrm{ZSM}-5$ & 299.9 & 0.18 & 2.50 \\
$\mathrm{Fe}_{0.75} \mathrm{Cu}_{0.25} / \mathrm{ZSM}-5$ & 297.1 & 0.18 & 2.45 \\
\hline
\end{tabular}

All the catalysts had an obvious hysteresis loop, which was H4 type (did not show in this article). However, after the copper and iron were incorporated through impregnation in the ZSM- 5 zeolite, the surface areas and pore volumes decreased compared with those of ZSM-5 zeolite. For example, the values of $\mathrm{Fe}_{0.25} \mathrm{Cu}_{0.75} /$ ZSM-5 decreased from $335.1 \mathrm{~m}^{2} \cdot \mathrm{g}^{-1}$ and $0.19 \mathrm{~cm}^{3} \cdot \mathrm{g}^{-1}$ to $298.0 \mathrm{~m}^{2}$. $\mathrm{g}^{-1}$ and $0.18 \mathrm{~cm}^{3} \cdot \mathrm{g}^{-1}$. The surface area of ZSM-5 support was obtained after thermal treatment. So the reason for the loss of surface area was more likely to be the covering of the external surface of ZSM-5 by copper and iron species and blocking of the pores of ZSM-5. After the mass ratio of $\mathrm{Cu} / \mathrm{Fe}$ was decreased, the surface areas and pore volumes of the catalysts still kept unchanged compared with those of $\mathrm{Fe}_{0.25} \mathrm{Cu}_{0.75} / \mathrm{ZSM}-5$ catalyst. Thus it could be concluded that the textural properties of catalysts made little contribution to the variation of reaction activity.

\subsection{XRD measurements}

Fig. 6 showed the XRD patterns of $\mathrm{Fe}_{1-x} \mathrm{Cu}_{x} / \mathrm{ZSM}-5$ catalysts. All the catalysts exhibited typical peaks of the ZSM-5 (PDF No. 39-0225) zeolite, indicating that the structure of ZSM-5 zeolite kept intact after impregnation. The intensities of the principle diffraction peaks of the $\mathrm{Fe}_{1-x} \mathrm{Cu}_{x} / \mathrm{ZSM}-5$ catalysts decreased compared with those of the ZSM-5, because the copper and iron had higher absorption coefficient for the XRD or the lower content of zeolite. ${ }^{20}$ For $\mathrm{Fe}_{1-x} \mathrm{Cu}_{x} / \mathrm{ZSM}-5$ catalysts, the peaks shifted to lower angles than the peaks of ZSM-5, while the values remained the same among $\mathrm{Fe}_{1-x} \mathrm{Cu}_{x} / \mathrm{ZSM}-5$ catalysts. That was to say, the addition of copper and iron could enlarge crystallite di-

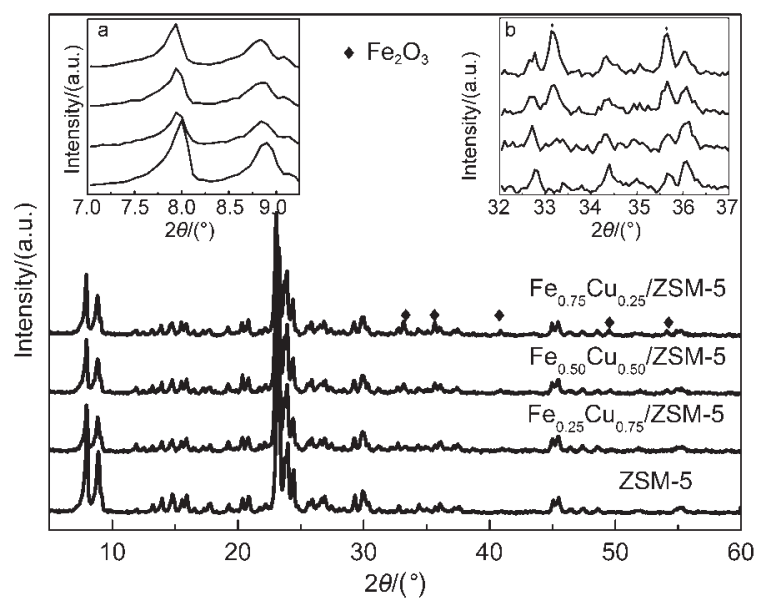

Fig.6 XRD patterns of different samples with $\mathrm{Cu} K_{a}$ radiation $(40 \mathrm{kV}, 25 \mathrm{~mA}, \lambda=0.15406 \mathrm{~nm})$

(a) the profiles of magnified peaks around $7^{\circ}-9^{\circ}$; (b) the profiles of magnified peaks around $32^{\circ}-37^{\circ}$ (ascribed to $\mathrm{Fe}_{2} \mathrm{O}_{3}$ ) 
mension of the pure ZSM-5, but the crystallite dimension remained unchanged with adjusting the mass ratio of $\mathrm{Cu} / \mathrm{Fe}$. It indicated that the crystallite dimension was not the main factor which influenced the activity. For $\mathrm{Fe}_{0.25} \mathrm{Cu}_{0.75} / \mathrm{ZSM}-5$ catalyst, no peaks associated with iron or copper compounds were found. It may be due to the interaction between copper and iron species or the low content of copper and iron species. It was in favor of the activity that $\mathrm{Cu}^{2+}$ and $\mathrm{Fe}^{3+}$ were completely incorporated into the crystal lattice of ZSM-5 zeolite.

But peaks (at $33.2^{\circ}, 35.6^{\circ}, 40.9^{\circ}, 49.5^{\circ}$, and $54.1^{\circ}$ ) ascribed to $\mathrm{Fe}_{2} \mathrm{O}_{3}$ (PDF No. 33-0664) were detected for $\mathrm{Fe}_{0.50} \mathrm{Cu}_{0.50} / Z \mathrm{ZM}-5$ catalyst when the iron loading was further increased. Combining with the result of activity and $\mathrm{N}_{2}$ selectivity, it can be concluded that the $\mathrm{Fe}_{2} \mathrm{O}_{3}$ species may facilitate the improvement of selectivity of $\mathrm{N}_{2}$ at higher temperatures, but did not contribute to the activity at low temperatures. ${ }^{12}$

\subsection{XPS results}

The XPS technique was used to understand the states of $\mathrm{Fe}$ and $\mathrm{Cu}$ species. Fig.7a showed the results of $\mathrm{Cu} 2 p_{3 / 2}$ of $\mathrm{Fe}_{1-x} \mathrm{Cu}_{x} / \mathrm{ZSM}-$ 5. Two peaks appeared at 933.1 and $934.8 \mathrm{eV}$, which were assigned to $\mathrm{CuO}$ species and $\mathrm{Cu}^{2+}$ in zeolite. ${ }^{21}$ In addition, we found that the amounts of $\mathrm{CuO}$ species and $\mathrm{Cu}^{2+}$ in zeolite increased by increasing the mass ratio of $\mathrm{Cu} / \mathrm{Fe}$, which was consistent with the activity of the catalysts. We could conclude that $\mathrm{CuO}$ species and $\mathrm{Cu}^{2+}$ in zeolite contributed to good activity at low temperatures. The selective catalytic oxidation of ammonia to nitrogen was a two-step route ${ }^{12,13}$ that involved the oxidation of ammonia to $\mathrm{NO}_{x}$
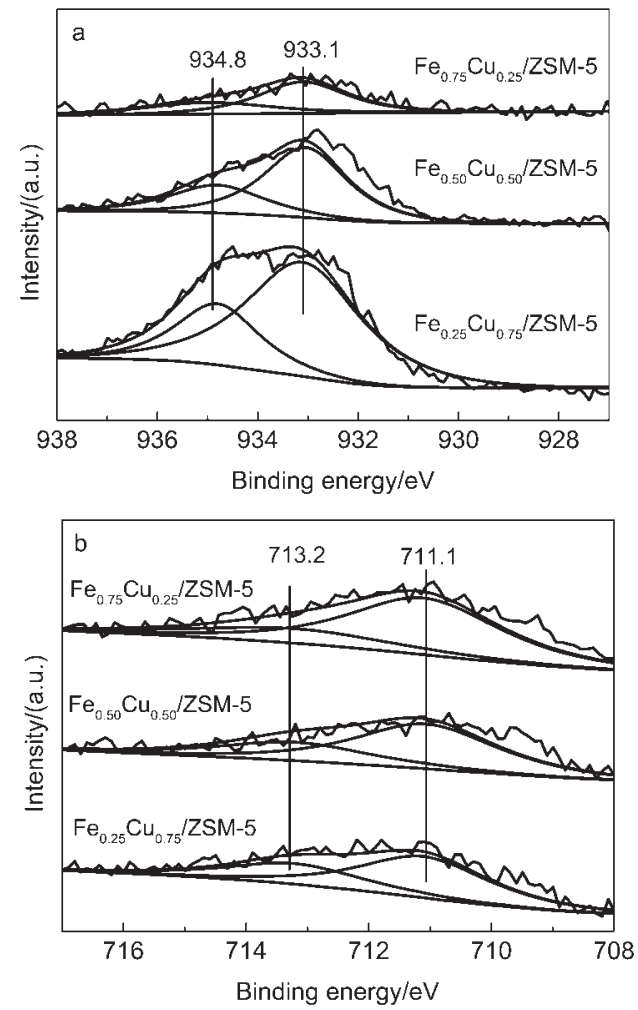

Fig.7 XPS results of $\mathrm{Cu} 2 p_{3 / 2}$ (a) and $\mathrm{Fe} 2 p_{3 / 2}$ (b) in $\mathrm{Fe}_{1-x} \mathrm{Cu}_{x} / \mathrm{ZSM}-5(x=0.75,0.50,0.25)$ at $\mathrm{CuO}$ sites and the selective catalytic reduction of $\mathrm{NO}_{x}$ to $\mathrm{N}_{2}$ at $\mathrm{Cu}^{2+}$ sites. ${ }^{22}$ Table 2 listed the XPS results of $\mathrm{Cu} 2 p_{3 / 2}$ and $\mathrm{Fe} 2 p_{3 / 2}$ for the samples. From Table 2, the atomic percentage of $\mathrm{Cu}^{2+}$ in $\mathrm{CuO}$ increased by increasing the mass ratio of $\mathrm{Cu} / \mathrm{Fe}$. It suggested that $\mathrm{CuO}$ species was a key factor to determine the activity at low temperatures. It might be due to the fact that the reaction of ammonia oxidation to $\mathrm{NO}_{x}$ was the rate determine step. ${ }^{23}$

Fig. 7b exhibited the spectra of $\mathrm{Fe} 2 p_{3 / 2}$ of $\mathrm{Fe}_{1-x} \mathrm{Cu}_{x} / \mathrm{ZSM}-5$ ( $x=$ $0.75,0.50,0.25)$ catalysts. Two peaks of Fe $2 p_{3 / 2}$ were located at 711.1 and $713.2 \mathrm{eV}$, higher than the binding energy $(710.7 \mathrm{eV})$ of $\mathrm{Fe}_{2} \mathrm{O}_{3}{ }^{24}$ which strongly suggested that the iron was present as $\mathrm{Fe}^{3+}$ species. ${ }^{25}$ The peak at $711.1 \mathrm{eV}$ was assigned to the $\mathrm{Fe}_{2} \mathrm{O}_{3}$ species and the peak at $713.2 \mathrm{eV}$ was the $\mathrm{Fe}^{3+}$ in the zeolite. From Fig. $7 \mathrm{~b}$ and Table 2, we could see that the peak area of $\mathrm{Fe}^{3+}$ in the zeolite kept unchanged, while the atomic percentage of $\mathrm{Fe}^{3+}$ in $\mathrm{Fe}_{2} \mathrm{O}_{3}$ was decreased by increasing the mass ratio of $\mathrm{Cu} / \mathrm{Fe}$. Combining with the activity and $\mathrm{N}_{2}$ selectivity, we could find out that $\mathrm{Fe}_{2} \mathrm{O}_{3}$ species contributed little to the SCO activity at low temperatures, which was consistent with the result of XRD. However, $\mathrm{Fe}_{2} \mathrm{O}_{3}$ species might improve the selectivity of $\mathrm{N}_{2}$ at high temperatures because $\mathrm{Fe}_{0.75} \mathrm{Cu}_{0.25} / \mathrm{ZSM}-5$ catalyst with the largest amounts of $\mathrm{Fe}_{2} \mathrm{O}_{3}$ species had the best $\mathrm{N}_{2}$ selectivity.

\section{$3.5 \mathrm{H}_{2}$-TPR result}

To understand the redox properties of the catalysts, the temperature-programmed reduction measurement was performed. $\mathrm{H}_{2}$ TPR of the pure ZSM- 5 was also performed, and no signal peaks of $\mathrm{H}_{2}$ consumption were found (did not show in this article). Therefore, the peaks for the catalysts were attributed to the reduction of copper and iron species. For $\mathrm{Fe}_{1_{-x}} \mathrm{Cu}_{x} / \mathrm{ZSM}-5$ catalysts, the peaks $\alpha_{1}$ and $\alpha_{2}$ were attributed to the reduction of copper species, which were assigned to the reduction of $\mathrm{Cu}^{2+}$ to $\mathrm{Cu}^{+}$and $\mathrm{Cu}^{+}$to $\mathrm{Cu}^{0}$, respectively. ${ }^{26}$ Moreover, the $\mathrm{H}_{2}$ consumption ratio of $\alpha_{1} / \alpha_{2}$ was around 1 , which indicted that the copper species were mostly present in the form of $\mathrm{Cu}^{2+}$. This result was consistent with the spectra of $\mathrm{Cu} 2 p_{3 / 2}$. On the other hand, the $\mathrm{H}_{2}$ consumptions of peaks $\beta_{1}-\beta_{3}$ at higher temperatures were assigned to the reduction of iron species. The peak $\beta_{1}$ was due to the reduction of $\mathrm{Fe}^{3+}$ in molecular sieves and the peak $\beta_{2}$ was ascribed to the reduction of $\mathrm{Fe}_{2} \mathrm{O}_{3}$ to $\mathrm{Fe}^{2+}$, the peak $\beta_{3}$ was attributed to the reduction of $\mathrm{Fe}^{2+}$ species to $\mathrm{Fe}^{0}$. In addition, we also found that the strength ratio of $\left(\beta_{1}+\beta_{2}\right) / \beta_{3}$ was about $1 / 2$, which exhibited that the iron species were mostly present in the form of $\mathrm{Fe}^{3+}$. Although $\mathrm{FeCl}_{2} \cdot 4 \mathrm{H}_{2} \mathrm{O}$ was the metal precursor, most iron species were present as $\mathrm{Fe}^{3+}$ after calcination, which was also proved by XPS.

Table 2 XPS results of $\mathrm{Cu} 2 p_{3 / 2}$ and $\mathrm{Fe} 2 p_{3 / 2}$ for the samples

\begin{tabular}{|c|c|c|c|c|c|}
\hline \multirow[b]{2}{*}{ Sample } & \multicolumn{2}{|c|}{$A / \%$} & \multicolumn{2}{|c|}{$A^{\prime} / \%$} & \multirow[b]{2}{*}{$m(\mathrm{Cu}) / m(\mathrm{Fe})$} \\
\hline & $\begin{array}{l}\mathrm{Cu}^{2+} \text { in } \\
\text { zeolite }\end{array}$ & $\begin{array}{c}\mathrm{Cu}^{2+} \text { in } \\
\mathrm{CuO}\end{array}$ & $\begin{array}{l}\mathrm{Fe}^{3+} \text { in } \\
\text { zeolite }\end{array}$ & $\begin{array}{l}\mathrm{Fe}^{3+} \text { in } \\
\mathrm{Fe}_{2} \mathrm{O}_{3}\end{array}$ & \\
\hline $\mathrm{Fe}_{0.25} \mathrm{Cu}_{0.75} / \mathrm{ZSM}-5$ & 28.2 & 71.8 & 34.5 & 65.5 & 2.3 \\
\hline $\mathrm{Fe}_{0.50} \mathrm{Cu}_{0.50} / \mathrm{ZSM}-5$ & 31.2 & 68.8 & 30.8 & 69.2 & 0.8 \\
\hline $\mathrm{Fe}_{0.75} \mathrm{Cu}_{0.25} / \mathrm{ZSM}-5$ & 34.8 & 65.2 & 21.9 & 78.1 & 0.2 \\
\hline
\end{tabular}

$A$ : atomic percent of $\mathrm{Cu}^{2+}$ in zeolite or $\mathrm{Cu}^{2+}$ in $\mathrm{CuO} ; A^{\prime}$ : atomic percent of $\mathrm{Fe}^{3+}$ in zeolite or $\mathrm{Fe}^{3+}$ in $\mathrm{Fe}_{2} \mathrm{O}_{3}$ 
Table 3 showed $\mathrm{H}_{2}$ consumption of catalysts. From Table 3, the amount of $\mathrm{H}_{2}$ consumption for peak $\alpha_{1}$ increased by increasing the mass ratio of $\mathrm{Cu} / \mathrm{Fe}$ at the low temperatures. This result was consistent with the activity of catalysts, larger amount of $\mathrm{Cu}^{2+}$ species contributed to better activity at low temperatures. The amount of $\mathrm{H}_{2}$ consumption for peak $\beta_{1}$ of $\mathrm{Fe}_{1_{-x}} \mathrm{Cu}_{x} / \mathrm{ZSM}-5$ ( $x=0.25$, $0.50,0.75)$ slightly increased from 37.5 to $48.0 \mu \mathrm{mol} \cdot \mathrm{g}^{-1}$ with increasing the amount of $\mathrm{Fe}$. The amount of $\mathrm{H}_{2}$ consumption for peak $\beta_{2}$ of $\mathrm{Fe}_{0.25} \mathrm{Cu}_{0.75} / \mathrm{ZSM}-5$ was $42.2 \mu \mathrm{mol} \cdot \mathrm{g}^{-1}$, when increased Fe loading, the value of $\mathrm{Fe}_{0.75} \mathrm{Cu}_{0.25} / \mathrm{ZSM}-5$ increased to $117.8 \mu \mathrm{mol}$ $\mathrm{g}^{-1}$. However, the activity did not get better with decreasing the mass ratio of $\mathrm{Cu} / \mathrm{Fe}$. It suggested that $\mathrm{Fe}_{2} \mathrm{O}_{3}$ contributed little to good activity at low temperatures.

In addition, the selectivity of $\mathrm{N}_{2}$ was significantly influenced by the reduction ability of the catalysts. The amount of $\mathrm{H}_{2}$ consumption for copper species at low temperatures increased with increasing the mass ratio of $\mathrm{Cu} / \mathrm{Fe}$. This result was consistent with the selectivity of the catalysts, and the amount of $\mathrm{H}_{2}$ consumption for iron species at high temperatures increased with decreasing the mass ratio of $\mathrm{Cu} / \mathrm{Fe}$, indicating that the catalysts with larger amount of iron had excellent reduction ability at high temperatures owe to the increasing of the amount of $\mathrm{Fe}_{2} \mathrm{O}_{3}$, it may be one reason for better $\mathrm{N}_{2}$ selectivity.

From the results of XPS and TPR, we can conclude that $\mathrm{Cu}^{2+}$ was a main factor to improve the activity and $\mathrm{N}_{2}$ selectivity. Furthermore, the rate- determine step $\left(\mathrm{NH}_{3}+\mathrm{O}_{2} \rightarrow \mathrm{NO}_{x}+\mathrm{H}_{2} \mathrm{O}\right)$ happened at $\mathrm{CuO}$ sites then selective catalytic reduction of $\mathrm{NO}_{x}$ to $\mathrm{N}_{2}$ at $\mathrm{Cu}^{2+}$ sites. In addition, $\mathrm{Fe}^{3+}$ could play an important role in increasing the $\mathrm{N}_{2}$ selectivity above $400{ }^{\circ} \mathrm{C}$.

Moreover, we also studied the reduction of iron species of $\mathrm{Fe}_{1} /$ ZSM-5. The $\mathrm{H}_{2}$ consumption peaks $\beta_{1}-\beta_{3}$ appeared at 448, 568, and $646{ }^{\circ} \mathrm{C}$. From Fig. 8 we found that the reduction temperatures

Table $3 \mathrm{H}_{2}$ consumption of catalysts

\begin{tabular}{|c|c|c|c|}
\hline Sample & Peak type & Peak temperature $/{ }^{\circ} \mathrm{C}$ & $\mathrm{H}_{2}$ consumption $/\left(\mu \mathrm{mol} \cdot \mathrm{g}^{-1}\right)$ \\
\hline \multirow{5}{*}{$\mathrm{Fe}_{0.25} \mathrm{Cu}_{0.75} / \mathrm{ZSM}-5$} & $\alpha_{1}$ & 245 & 44.1 \\
\hline & $\alpha_{2}$ & 300 & 53.3 \\
\hline & $\beta_{1}$ & 349 & 37.5 \\
\hline & $\beta_{2}$ & 384 & 42.2 \\
\hline & $\beta_{3}$ & 469 & 146.3 \\
\hline \multirow[t]{5}{*}{$\mathrm{Fe}_{0.50} \mathrm{Cu}_{0.50} / \mathrm{ZSM}-5$} & $\alpha_{1}$ & 220 & 40.9 \\
\hline & $\alpha_{2}$ & 300 & 36.2 \\
\hline & $\beta_{1}$ & 387 & 45.6 \\
\hline & $\beta_{2}$ & 444 & 44.7 \\
\hline & $\beta_{3}$ & 523 & 195.8 \\
\hline \multirow[t]{5}{*}{$\mathrm{Fe}_{0.75} \mathrm{Cu}_{0.25} / \mathrm{ZSM}-5$} & $\alpha_{1}$ & 216 & 38.1 \\
\hline & $\alpha_{2}$ & 296 & 35.8 \\
\hline & $\beta_{1}$ & 393 & 48.0 \\
\hline & $\beta_{2}$ & 478 & 117.8 \\
\hline & $\beta_{3}$ & 588 & 289.2 \\
\hline \multirow[t]{3}{*}{$\mathrm{Fe}_{1} / \mathrm{ZSM}-5$} & $\beta_{1}$ & 448 & 88.4 \\
\hline & $\beta_{2}$ & 568 & 137.3 \\
\hline & $\beta_{3}$ & 646 & 403.5 \\
\hline
\end{tabular}

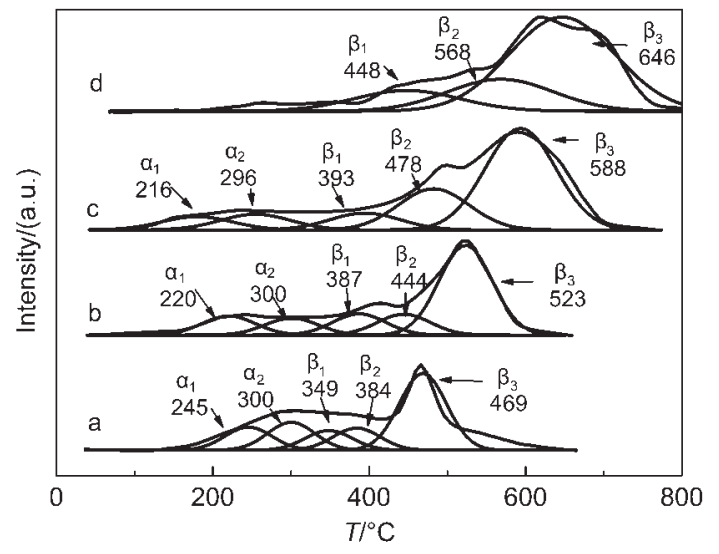

Fig.8 TPR profiles of $\mathrm{Fe}_{0.25} \mathrm{Cu}_{0.75} / \mathrm{ZSM}-5$ (a), $\mathrm{Fe}_{0.50} \mathrm{Cu}_{0.50} / \mathrm{ZSM}-5$ (b), $\mathrm{Fe}_{0.75} \mathrm{Cu}_{0.25} / \mathrm{ZSM}-5$ (c), and $\mathrm{Fe}_{1} / \mathrm{ZSM}-5$ (d)

of copper species moved to lower values with decreasing loading amount of copper, and the reduction temperatures of iron species shifted to lower values as the amount of iron decreased, the gradual shifts of reduction temperature may be due to the interaction between copper and iron species. ${ }^{21}$ The interaction was beneficial to improve the reduction ability of the active species, which was considered as one reason for good activity.

\section{6 $\mathrm{NH}_{3}$-TPD result}

In order to understand the strength and amount of different acid sites, temperature-programmed desorption of ammonia was carried out. Fig. 9 showed the $\mathrm{NH}_{3}$-TPD profiles on ZSM-5 and $\mathrm{Fe}_{1-x} \mathrm{Cu}_{x} / \mathrm{ZSM}-5$ catalysts.

Two main desorption peaks were found at about 211 and $436{ }^{\circ} \mathrm{C}$ for parent ZSM-5, corresponding to the weak and the strong acid sites, respectively. The desorption peak at the lower temperatures had been proven to generate from the physically adsorbed $\mathrm{NH}_{3}$ or ammonium species, ${ }^{27}$ probably hydrogen bonded, but not the ammonia species adsorbed on acid sites and the peak at higher temperatures was ascribed to $\mathrm{NH}_{3}$ strongly adsorbed which could determine the property of acid sites.

The peak $\beta$ for the $\mathrm{Fe}_{0.25} \mathrm{Cu}_{0.75} / \mathrm{ZSM}-5$ at about $365^{\circ} \mathrm{C}$ moved to a lower temperature than parent ZSM-5, which implied that the

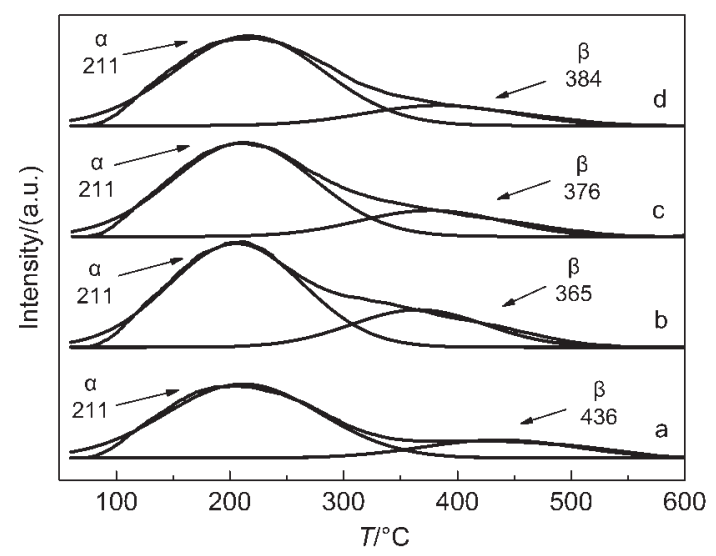

Fig.9 TPD profiles of pure ZSM-5 (a), $\mathrm{Fe}_{0.25} \mathrm{Cu}_{0.75} / \mathrm{ZSM}-5$ (b), $\mathrm{Fe}_{0.50} \mathrm{Cu}_{0.50} / \mathrm{ZSM}-5$ (c), and $\mathrm{Fe}_{0.75} \mathrm{Cu}_{0.25} / \mathrm{ZSM}-5$ (d) 
strength of the peak $\beta$ was decreased. In addition, the peak $\beta$ shifted to a higher temperature with increasing the amount of iron, which may be caused by the interaction between copper and iron. It could explain that the activity turned worse at lower temperatures after increasing the iron content.

From the literature, ${ }^{12}$ the FTIR result showed that $\mathrm{NH}_{3}$ was adsorbed on the acid sites and the intensity of adsorbed ammonia species decreased with the temperature increasing during researching the IR spectra in flowing $\mathrm{NH}_{3}$ and $\mathrm{O}_{2}$. Accordingly, we could deduce that larger number of acid sites was conducive to better activity. Moreover, from Fig.9 we also found that the area of peak $\beta$ of $\mathrm{Fe}_{1-x} \mathrm{Cu}_{x} / \mathrm{ZSM}-5$ catalysts increased with increasing the mass ratio of $\mathrm{Cu} / \mathrm{Fe}$, and $\mathrm{Fe}_{0.25} \mathrm{Cu}_{0.75} / \mathrm{ZSM}-5$ catalyst with the largest mass ratio of $\mathrm{Cu} / \mathrm{Fe}$ in this study had the best activity, indicating that the increase of the number of acid sites was corresponded to the activity date, we could deduce that the activity of the catalysts had a close relationship with the acid amounts. In other words, the conversion of ammonia increased with increasing the acid amounts.

\section{Conclusions}

In summary, the iron and copper bimetallic catalysts demonstrated high activity and excellent selectivity of $\mathrm{N}_{2}$. The activity and $\mathrm{N}_{2}$ selectivity in low temperature range were increased by increasing the mass ratio of $\mathrm{Cu} / \mathrm{Fe}$. In contrast, the higher $\mathrm{N}_{2}$ selectivity was achieved with larger amount of iron at higher temperatures. $\mathrm{Fe}_{0.25} \mathrm{Cu}_{0.75} / \mathrm{ZSM}-5$ had the best activity and high $\mathrm{N}_{2}$ selectivity. The characterization results indicated that strong interaction between copper and iron species was obtained. And the $\mathrm{Cu}$ and $\mathrm{Fe}$ species were mostly presented as $\mathrm{Cu}^{2+}$ and $\mathrm{Fe}^{3+}$, respectively. The activity increased with the increase in the amount of the $\mathrm{Cu}$ active species at low temperatures. Larger amount of $\mathrm{Fe}_{2} \mathrm{O}_{3}$ was a probable reason for better $\mathrm{N}_{2}$ selectivity at high temperatures. In addition, the acid content, strength of catalysts, and the redox property of catalysts also played important roles in the ammonia oxidation reaction.

\section{References}

(1) Krupa, S. V. Environ. Pollut. 2003, 124, 179. doi: 10.1016/ S0269-7491(02)00434-7

(2) Hung, C. M. Powder Technol. 2009, 196, 56. doi: 10.1016/j. powtec.2009.07.001

(3) Akah, A.; Cundy, C.; Garforth, A. Appl. Catal. B: Environ. 2005, 59, 221. doi: 10.1016/j.apcatb.2004.10.020

(4) Sobczyk, D. P.; Hensen, E. J. M.; Jong, A. M. D.; Santen, R. A. V. Top. Catal. 2003, 23, 1. doi: 10.1023/A:1024834800948

(5) Hung, C. M. Powder Technol. 2010, 200, 78. doi: 10.1016/j. powtec.2010.02.014

(6) Broek, A. C. M. V. D.; Grondelle, J. V.; Santen, R. A. V. J. Catal.1999, 185, 297. doi: 10.1006/jcat.1999.2506

(7) Gang, L.; Anderson, B. G.; Grondelle, J. V.; Santen, R. A. V.
Appl. Catal. B: Environ. 2003, 40, 101. doi: 10.1016/S09263373(02)00129-7

(8) Zhang, L.; Zhang, C. B.; He, H. J. Catal. 2009, 261, 101. doi: 10.1016/j.jcat.2008.11.004

(9) Zhang, L.; He, H. J. Catal. 2009, 268, 18. doi: 10.1016/j. jcat.2009.08.011

(10) Long, R. Q.; Yang, R. T. J. Catal. 2002, 207, 158. doi: 10.1006/ jcat.2002.3545

(11) Cui, X. Z.; Zhou, J.; Ye, Z. Q.; Chen, H. R.; Li, L.; Ruan, M. L.; Shi, J. L. J. Catal. 2010, 270, 310. doi: 10.1016/j. jcat.2010.01.005

(12) Qi, G. S.; Yang, R. T. Appl. Catal. A: Gen. 2005, 287, 25. doi: 10.1016/j.apcata.2005.03.006

(13) Qi, G. S.; Gatt, J. E.; Yang, R. T. J. Catal. 2004, 226, 120. doi: 10.1016/j.jcat.2004.05.023

(14) Long, R. Q.; Yang, R. T. J. Catal. 2001, 201, 145. doi: 10.1006/ jcat.2001.3234

(15) Gang, L.; Grondelle, J. V.; Anderson, B. G.; Santen, R. A. V. J. Catal. 1999, 186, 100. doi: 10.1006/jcat.1999.2524

(16) Metkar, P. S.; Harold, M. P.; Balakotaiah, V. Appl. Catal. B: Environ. 2012, 111, 67.

(17) Song, S. Q.; Jiang, S. J. Appl. Catal. B: Environ. 2012, 117, 346

(18) Liang, C. X.; Li, X. Y.; Qu, Z. P.; Tade, M.; Liu, S. M. Appl. Surf. Sci. 2012, 258, 3738. doi: 10.1016/j.apsusc.2011.12.017

(19) Shi, L.; Yu, T.; Wang, X. Q.; Wang, J.; Shen, M. Q. Acta Phys. -Chim. Sin. 2013, 29, 1550. [石 琳, 于 铁, 王欣全, 王 军, 沈美庆. 物理化学学报, 2013, 29, 1550.] doi: 10.3866 / PKU.WHXB201304283

(20) Rauscher, M.; Kesore, K.; Mönnig, R.; Schwieger, W.; Tißler, A.; Turek, T. Appl. Catal. A: Gen. 1999, 184, 249. doi: 10.1016/ S0926-860X(99)00088-5

(21) Zhang, T.; Liu, J.; Wang, D. X.; Zhao, Z.; Wei, Y. C.; Cheng, K.; Jiang, G. Y.; Duan, A. J. Appl. Catal. B: Environ. 2014, 148 , 520.

(22) Wang, J.; Huang, Y.; Yu, T.; Zhu, S. C.; Shen, M. Q.; Li, W.; Wang, J. Q. Catal. Sci. Technol. 2014, 4, 3004. doi: 10.1039/ c4cy00451e

(23) Brüggemann, T. C.; Keil, F. J. J. Phys. Chem. C 2009, 113, 13860 .

(24) Wagner, C. D.; Riggs, W. M.; Davis, L. E.; Moulder, J. F. Handbook of X-ray Photoelectron Spectroscopy, 1st ed.; Muilenberg, G. E. Ed. Perkin-Elmer Corporation: Eden Prairie, Minnesota, USA, 1979.

(25) Gurgul, J.; Ła tka, K.; Hnat, I.; Rynkowski, J.; Dzwigaj, S. Microporous Mesoporous Mat. 2013, 168, 1. doi: 10.1016/j. micromeso.2012.09.015

(26) Lisi, L.; Pirone, R.; Russo, G.; Stanzione, V. Chem. Eng. J. 2009, 154, 341. doi: 10.1016/j.cej.2009.04.025

(27) Long, R. Q.; Yang, R. T. J. Catal. 2001, 198, 20. doi: 10.1006/ jcat.2000.3118 